\title{
Sosyal Bilgiler Dersi Örneğinde Öğrencilere ve Ailelerine Göre Organ Bağışı ${ }^{1}$
}

\section{Organ Donation According to the Students and their Families in Example of the Social Studies Course}

\author{
Nazlı GÖKÇE \\ Hacer ÖZER \\ Zülal KİLCİ \\ Anadolu University, Turkey \\ Anadolu University, Turkey \\ Anadolu University, Turkey \\ nazliu@anadolu.edu.tr \\ hacer.ozr@gmail.com \\ zulalkilci@hotmail.com
}

\begin{abstract}
$\ddot{O} \mathbf{z}$
Türkiye'de son yıllarda okullarda Sosyal Bilgiler, Fen Bilimleri gibi farklı derslerin öğretim programlarında organ bağı̧sı konusuna yer verildiği görülmektedir. Organ bağışı; toplumsal, yaşamsal, kültürel, hukuksal, dini boyutlarıyla Sosyal Bilgiler dersi için oldukça önemlidir. Bu nedenle araştırmada, Sosyal Bilgiler dersinde organ bağışı konusunu işlemiş olan öğrencilerin ve ailelerinin bu konudaki görüşlerinin belirlenmesi amaçlanmıştır. Araştırmada nitel araştırma yöntemi kullanılmış, 2014-2015 bahar döneminde, 10 öğrenci ve 10 veli ile yarı yapılandırılmış görüşmeler yapılmış, toplanan veriler içerik analizi ile çözümlenmiştir. Araştırmanın sonunda öğrenciler ve ailelerinin organ bağışını; çoğunlukla hayat kurtardığı, yardımlaşmayı sağladığı ve yaşam sevinci oluşturduğu için önemli gördükleri belirlenmiştir. Ailelerin Türkiye'de organ bağışının durumuna ilişkin bilgilerinin sınırlı olduğu, dini inançlar ve kültürel yapının organ bağışında bulunmayı engellediğini düşündükleri, organ bağışı konusunda yaşantıları olan insanların konuya bakış açılarının farklılaşıs̆ı̆ı ve daha duyarlı oldukları, ancak organ bağışı konusuna çok fazla ilgi duymadıkları ve merak etmedikleri bulunmuştur. Ayrıca ailelerin, çocuklarının organ bağışı ile ilgili ne bildiklerinden yeterince haberdar olmadıkları ve çoğunlukla çocukları ile bu konuda herhangi bir paylaşımlarının olmadığı sonuçlarına ulaşılmıştır. Araştırmanın sonuçları doğrultusunda, öğrenciler ve ailelerinde organ bağışı konusundaki farkındalığı ve ilgiyi arttırmak amacıyla çeşitli öneriler getirilmiştir.
\end{abstract}

Anahtar Kelimeler: Organ bağışı, Sosyal bilgiler, İlköğretim, 7. sınıf öğrencisi, Aile.

\footnotetext{
${ }^{1}$ Araştırma makalesi, İlk gönderim tarihi: 08.01.2016 Kabul tarihi: 22.01.2016
} 


\begin{abstract}
The topic of organ donation has recently been covered in the curricula of different courses such as Social Studies, Science and Technology in Turkey. Organ donation is of great importance for the Social Studies course in terms of its societal, biological, cultural, judicial and religious aspects. Therefore, this study aimed to determine the views of students and their parents regarding organ donation after studying the subject in Social Studies course. The qualitative research method was employed in this study. The semi-structured interviews with 10 students and 10 parents were conducted in 2014-2015 spring term and the results were examined through content analysis. The results revealed that the students and parents value the organ donation mostly because it saves life, provides a basis for helping each other, and creates joy of life. It was found that the parents' knowledge about organ donation is limited. They believe that the religious and cultural structure hinder people from organ donation and the views of people who have experience with organ donation may change and they become more sensitive to the issue; however; they are not so interested in organ donation. The study also found that parents are not necessarily aware of what their students know about organ donation and they do not interact with their children about this subject. In light of the study results, some recommendations are presented to raise awareness in students and their parents regarding organ donation.
\end{abstract}

Keywords: Organ donation, Social studies, Primary education, 7th grade students, Parents.

\title{
Giriş
}

Dünya'da bilim ve teknolojide yaşanan gelişmeler, güncel sorunların çözümüne yönelik yeni uygulamaları da beraberinde getirmektedir. Bunlardan biri, sağlık alanında yapılan "organ bağışı" konusundaki çalışmalardır. Tüm dünyada olduğu gibi Türkiye'de de organ yetmezliği nedeniyle sağlığını kaybeden binlerce hasta bulunmaktadır. Organ yetmezliğinden kurtulmak için tek yol ise organ nakli olmaktır. Gelişmiş ülkelerde bir milyonda 20-30 olan kadavradan organ bağışı, İspanya'da 34,6, İtalya'da 21,1, Fransa'da 20,9, ABD'de 20, Almanya'da 13,8, Yunanistan'da 6,2, Türkiye genelinde ise 2,0'dır (Yeter ve Demirtaş, 2015). İstatistikler Türkiye'de organ bağışlarının son derece yetersiz olduğunu göstermektedir.

Çeşitli nedenlerle tıbbi tedavisi olamayan hastalıklarda, bireylerin hayatlarını kurtarmak ve yaşam sürelerini artırmak amacıyla uygulanan tedavi yöntemlerinden birisi olan organ nakli (Özdağ, 2001) çoğunlukla organ bağışı sonucunda gerçekleştirilebilmektedir. Türkiye'de organ bağışı ve nakli 3 Haziran 1979 tarih ve 2238 sayılı "Organ ve Doku Alınması, Saklanması, 
Aşılanması ve Nakli Hakkındaki Kanun" ile yapılmaktadır. Bu yasa çerçevesinde organ bağışı, ya kişinin hayatta iken organ bağışı yaptığını "organ bağış kartı” edinerek yasallaştırması ya da kişinin tıbben ölümünün tespitinden sonra, hastanın yakınlarının organ bağışında bulunması ile yapılmaktadır (Akış ve diğerleri, 2008; Özdağ, 2004). Ancak gelinen noktada Türkiye'de organ bağışı yeterli seviyede olmadığından ve tamamen gönüllüğe dayalı olduğundan istenilen düzeyde başarı elde edilememektedir (Demir, 2008). Bu, çoğu zaman bireylerin bilgi yetersizliğinden, dini inançlarından, deneyimlerinden, korku ve kişiliklerinden kaynaklanabilmektedir. Bu bağlamda konuya dikkat çekmek, bireylere farkındalık kazandırmak açısından oldukça önemlidir (Kılıç, 2010; Özer, 2008).

Organ bağışı, yaşamsal öneme sahip bir konu olmakla birlikte aynı zamanda, ülkelerin ekonomilerine de büyük yük getirmektedir. Bugün diyaliz makinelerine bağlı olarak yaşayan ve organ nakli olmayı bekleyen kişilerin sağlık giderleri trilyonları bulabilmektedir. Organ bağışı çok boyutlu bir konu olup, bu konuda yapılan/yapılacak eğitim çalışmalarının önemi büyüktür. Sağlık Bakanlığı, Milli Eğitim Bakanlı̆̆ı ile işbirliği içerisinde Türkiye genelinde ilk ve ortaöğretim okullarında öğrenim gören tüm öğrencilerin ve ailelerinin bilinçlendirilmesi ve daha duyarlı hale getirilmesi amacıyla eğitim programları düzenlemekte, bu kapsamda 3-9 Kasım Organ Nakli Haftasında okullarda çeşitli etkinlikler gerçekleştirilmektedir.

Son yıllarda okullarda Fen Bilimleri, Sosyal Bilgiler gibi farklı derslerin öğretim programlarında da organ bağı̧̧ı konusuna yer verildiği görülmektedir. Örneğin; Fen Bilimleri dersi öğretim programında ara disiplin etkinlik örneklerinde 7. sınıf düzeyinde "Vücudumuzda Sistemler/ Canlılar ve Hayat" ünitesinde, organ bağışı ve organ nakli konusu işlenmektedir. Yapılan çalışma ile öğrencilerin "organ bağışı ve organ naklinin toplumsal dayanışma açısından önemini kavramaları" amaçlanmaktadır (Milli Eğitim Bakanlığı [MEB], 2013).

Dünya'da, eğitim programlarında organ bağışı konusunda yeni yaklaşımlar dikkat çekmektedir (Cantarovich, 2002'den aktaran, Burra, 2005). Örneğin Siebelink, Albers, Roodbol, ve Van de Wiel (2014a) tarafından organ bağışı konusunda aile katılımını içeren bir eğitim programı hazırlanmış ve bu programın ilköğretim öğrencileri ve aileleri üzerinde etkileri ortaya koyan bir araştırma yapılmıştır. Bununla birlikte, program hakkında programı uygulayan öğretmenlerle de görüşme yapılmıştır. Araştırmanın sonunda organ bağışı konusundaki eğitim için çocuklarda en iyi yaşın 10-11 yaş civarında olduğu sonucuna ulaşılmıştır. Türkiye'de de farklı eğitim 
programlarında olmakla birlikte organ bağışı konusuna; Sosyal Bilgiler dersinde yaklaşık bu yaş grubunda ve 6. sınıf düzeyinde yer verildiği görülmektedir. Sosyal Bilgiler, sürekli değişen dünyada meydana gelen olaylara ayak uydurarak, karar verebilen, problemlere çözüm üretebilen etkili vatandaşlar yetiştirmek amacıyla sosyal bilimlerden aldığı bilgi ve yöntemleri harmanlayarak kullanılan bir öğretim programıdır (Sönmez, 1997; Doğanay, 2005). İlköğretim düzeyinde 4., 5., 6. ve 7. sinıflarda uygulanmakta, farklı öğrenme alanları farklı sınıf düzeylerinde değişen üniteler ile işlenmektedir. Sosyal Bilgiler Dersi Öğretim Programı'nda; 6. sınıf düzeyinde "Bilim, Teknoloji ve Toplum" öğrenme alanı, "Elektronik Yüzyll” ünitesinde "Doku ve Organ Bağışı" konusuna yer verildiği görülmektedir. Bu konuyla ilgili olarak programda "tıp alanındaki buluş ve gelişmelerle insan hayatı ve toplumsal dayanışma arasındaki ilişkiyi ifade eder" kazanımı yer almaktadır. Bu kazanımı gerçekleştirmek için de önerilen etkinlik; "Bir Hayat Kurtarmak (Bağışladığı organ ile birkaç insanın hayatını değiştiren kişilerin öyküsü ve organ nakli konusu ele alınır.)" biçimindedir (MEB, 2005). Programda yer verilen kazanım ve etkinliğin öğrencilerin organ bağışı konusundaki görüşlerini ne kadar etkilediğinin araştırmaya değer bir konu olduğu düşünülmektedir. Dolayısıyla bu sınıf düzeyinde organ bağışı konusunu öğrenen öğrencilerin konuyla ilgili görüşlerinin ortaya konulmasının, yapılan eğitimin başarısı hakkında fikir verebileceği düşünülmektedir.

Organ bağışının eğitimdeki yerine ilişkin Türkiye'de çoğunlukla üniversite öğrencilerine yönelik araştırmalar yapılmıştır. Bu çalışmalarda; üniversite öğrencilerinin organ bağışına ilişkin görüşleri (Bölükbaş, Eyüpoğlu ve Kurt, 2004; Özer ve diğerleri, 2008; Savaşer, Mutlu, Çağlar, Doğan ve Canbulut, 2012) ve bilgileri (Kavurmacı, Karabulut ve Koç, 2014; Özmen, Çetinkaya, Sarızeybek ve Zeybek, 2008) belirlenmiştir. Ayrıca öğrencilerin tutumları (Doğan, 2012; Vicdan, Peker ve Üçer, 2011) ve tutumlarına etki eden faktörler (Yaşar ve diğerleri, 2008) incelenmiştir. Bunların dışındaki çalışmalarda; toplumun, hasta yakınlarının ya da sağlık çalışanlarının organ bağışı konusundaki bilgi, tutum, davranış ve görüşlerinin belirlenmeye çalışıldığı görülmektedir (Çelebi, Balık, Yılmaz ve Polat, 2002; Yücetin, Keçecioğlu ve Ersoy, 2003; Özkan ve Yılmaz, 2009; Balc1 ve Şahingöz, 2014; Güngörmüş ve Dayapoğlu, 2014).

Yurt dışında yapılan çalışmalarda ise; farklı yaş grupları ile yapılan araştırmalar dikkat çekmektedir. Çoğunlukla eğitimde organ bağışı konusundaki uygulamalar ve geliştirilen programlar ele alınmaktadır (Annadurai, Mani ve Ramasamy, 2012; Siebelink ve diğerleri, 2014; 
Vinokur ve diğerleri, 2006). Ayrıca öğrenci, aileler ve öğretmenlerin organ bağışına ilişkin bilgileri (Zhang ve diğerleri, 2007) tutumları (Chen ve diğerleri,2006; Perenc, Radochonski ve Radochonski, 2012) ve davranışları (Feeley ve Servoss, 2005) tespit edilmektedir.

Cheng, Ho, Ho ve Wong (2005), "Hong Kong'da organ bağışına ilişkin tutumlar üzerine bir bakış" adlı çalışmalarında, 1996-2004 yılları arasında bu konuda yapılmış araştırmaları, araştırmalarda uygulanan anket ve yapılan görüşmeleri incelemişlerdir. Çalışmanın sonunda, organ bağışına ilişkin insanların gönüllüğünü desteklemek için yeni yaklaşımlara başvurulması gerektiği sonucuna ulaşmışlardır. Feeley ve Servoss (2005), öğrencilerin organ bağış1 konusundaki niyetlerini incelemek amacıyla, 502 üniversite öğrencisine anket uygulamışlar ve genellikle öğrencilerin organ bağışı konusuna karşı pozitif bit tutum sergilediklerini bulmuşlardır. Febrora ve diğerleri (2014) de, İspanya'nın güneydoğusundaki ortaokul öğrencileri ve öğretmenlerinin organ bağışı ve nakline ilişkin tutumlarını ve bilgilerini analiz etmişlerdir.

Organ bağışı konusunda özellikle son yıllarda çeşitli çalışmalar yapılmakta, bu çalışmalarda da çoğunlukla nicel araştırma yöntemlerinin kullanıldı̆̆ını görülmektedir. Türkiye'de ise ilköğretim düzeyinde ve Sosyal Bilgiler eğitiminde organ bağışı konusunu ele alan herhangi bir çalışmaya rastlanmamaktadır. Bu nedenle araştırmada ilköğretim düzeyinde 6. sınıf Sosyal Bilgiler dersinde organ bağışı konusunu görmüş olan öğrencilerin konuya ilişkin görüşlerinin alınması amaçlanmıştır. Ancak bu konuda çocukların ailelerinin görüş ve tutumlarının da önemli olduğu düşünüldüğünden bu araştırmada 6 . Sınıfta organ bağışı konusunu işlemiş olan öğrencilerin ve velilerinin organ bağışı konusundaki görüşlerinin belirlenmesi amaçlanmıştır. Araştırmada belirlenen amaç doğrultusunda şu sorulara yanıt aranmıştır:

- 7. Sınıf öğrencilerinin ve velilerinin organ bağışı ve önemine ilişkin görüşleri nelerdir?

- 7. Sınıf öğrencilerinin ve velilerinin organ bağışı konusundaki bilgileri ve bilgi kaynaklarına ilişkin görüşleri nelerdir?

- 7. Sınıf öğrenci velilerinin, Türkiye'de organ bağışının durumuna ilişkin görüşleri nelerdir?

- 7. sınıf öğrenci velilerinin organ bağışında bulunma istekleri ve merak ettikleri konulara ilişkin görüşleri nelerdir?

- Velilerin çocuklarının organ bağışı konusundaki bilgilerine ve bu konudaki ortak paylaşımlarına ilişkin görüşleri nelerdir? 
- 7. Sınıf öğrencilerinin Sosyal Bilgiler dersinde organ bağışı konusunun işlenişine ilişkin önerileri nelerdir?

\section{Yöntem}

\section{Araştırma Modeli}

Organ bağışı konusunda 7. sınıf öğrencilerinin ve ailelerinin görüşlerini ortaya koymayı amaçlayan bu araştırmada nitel araştırma yöntemi benimsenmiştir. Nitel araştırmalar bireylerin algılarına, deneyimlerine ve değerlendirmelerine odaklanmakta, olay ve olguları bireylerin bakış açılarıyla görmeye olanak tanımaktadırlar (Yıldırım ve Şimşek, 2013). Araştırma nitel araştırma desenlerinden olgu bilimden yararlanılmıştır. Olgu bilimde, bireyin olguya ilişkin deneyimleri nelerdir? Bu olguya ilişkin deneyimlerini etkileyen ortam ve koşullar nelerdir?” gibi sorulara yanit aranmaktadır (Creswell, 2007, s. 61-62).

\section{Katılımcilar}

Araştırmada katılımcıların belirlenmesinde öğrenciler için; Sosyal Bilgiler dersinde organ bağışı konusunu işlemiş olmak, aileler için ise, görüşme yapılan öğrencilerin aileleri olmak koşulları aranmıştır. Araştırmaya 6. sınıf Sosyal Bilgiler dersinde organ bağışı konusunu işlemiş; 6 erkek, 4 kadın olmak üzere toplam 10 kişiden oluşan 7. sınıf öğrencileri katılmıştır. Bu öğrencilerin velileri olan katılımcıların kişisel özellikleri Tablo 1'de sunulmuştur.

\section{Tablo 1}

Araştırmaya Katılan Velilerin Kişisel Özellikleri

\begin{tabular}{llc}
\hline & & $\begin{array}{c}\text { Frekans } \\
\text { (f) }\end{array}$ \\
\hline \multirow{3}{*}{ Cinsiyet } & Kadın & 9 \\
& Erkek & 1 \\
\hline \multirow{2}{*}{ Ŏğrenim Düzeyi } & Üniversite mezunu & 1 \\
\multirow{3}{*}{ Mesleği } & Lise mezunu & 9 \\
& Ev hanımı & 7 \\
& Esnaf & 1 \\
& Emekli memur & 1 \\
\hline \multirow{3}{*}{ Yaş } & $45-49$ & 5 \\
& $40-44$ & 2 \\
& $35-39$ & 3 \\
\hline & $5000-5999$ & 1 \\
& $4000-4999 \mathrm{TL}$ & 3
\end{tabular}




\begin{tabular}{lcc} 
Aylık Gelir Durumu & $3000-3999$ TL & 3 \\
& $2000-2999$ TL & 2 \\
& $1000-1999$ TL & 1 \\
\hline Toplam & & 10 \\
\hline
\end{tabular}

\section{Verilerin Toplanması ve Analizi}

Araştırma verileri, 2014-2015 eğitim-öğretim y1lı bahar döneminde yarı yapılandırılmış görüşmeler yoluyla toplanmıştır. Öncesinde Anadolu Üniversitesinden etik kurul onayı ve Eskişehir İl Milli Eğitim Müdürlüğünden araştırma izni alınmıştır. Olgubilim deseninin benimsendiği araştırmalarda, derinlemesine bilgi edinmek için katılımcılarla birden fazla görüşme gerçekleştirilmektedir (Creswell, 2007, s. 61). İlk görüşmelerde katılımcıların konuya ilişkin bakış açılarını daha derinlemesine anlamak, onlara ek sorular sorabilmek, sorulara verdikleri cevapları örneklendirmeleri veya ayrıntılı açıklamalarını istemek ve görüşmeleri belli düzende gerçekleştirmek (Bogdan ve Biklen, 2007) amacıyla yarı-yapılandırılmış görüşme formları düzenlenmiştir. Görüşme formları; kişisel bilgiler ve görüşme soruları olmak üzere iki bölümden oluşmuştur. Araştırmanın amaçları doğrultusunda 7. sınıf öğrencileri ve velileri için ayrı ayrı hazırlanan görüşme formlarında; "organ bağışı ve önemine ilişkin görüşleriniz nelerdir? Organ bağışı konusunda neler biliyorsunuz? Bu bilgileri hangi kaynaklardan öğrendiniz?...” gibi sorular yer almıştır. Görüşme sorularının geçerliğini anlamak için uzman görüşü alınmış, soruların anlaşı1ırlığını belirlemek için de bir öğrenci ve bir veliyle pilot uygulama yapılmıştır. Görüşme formuna son biçimi verildikten sonra veri toplama sürecine geçilmiştir. Öğrenciler ve velileri ile gönüllülük ilkesine dayalı olarak görüşmeler gerçekleştirilmiştir. Görüşmeler için öğrencilerden ve velilerinden randevu alınmış, onlarla buluşulduğunda görüşme ile ilgili tüm ayrıntıları içeren yazılı bir bilgilendirme belgesi sunulmuş ve izin belgesi imzalattırılmıştır. İlk görüşmelerde toplanan veriler dikkate alınarak, söylediklerini daha ayrıntılı açıklaması için her bir öğrenci ve veliyle ikinci kez görüşme yapılmıştır. Tüm görüşmelerin, sessiz bir ortamda ve samimi bir biçimde gerçekleştirilmesine özen gösterilmiş, araştırmacının soru sorma ve dinleme işini daha etkili bir biçimde sürdürebilmesi için ses kayıt cihazı kullanılmıştır. Görüşmeler ortalama 25-30 dakika sürmüştür.

Veriler içerik analizi ile çözümlenmiştir. İçerik analizinde temel amaç, toplanan verileri açıklayabilecek kavramlara ve ilişkilere ulaşmaktır. Bu bağlamda içerik analizi ile veriler tanımlanmaya, verilerin içinde saklı olabilecek gerçekler ortaya çıkarılmaya çalışılmaktadır. Analizdeki temel işlem; birbirine benzeyen verilerin belirli kavramlar ve temalar çerçevesinde bir 
araya getirilmesi ve bunların okuyucunun anlayabileceği bir biçimde düzenlenip yorumlanmasıdır (Yıldırım ve Şimşek, 2013). Öncelikle yazılı döküm haline getirilen yarıyapılandırılmış görüsşme verileri birkaç kez okunmuştur. Sonra verilerdeki kelimeler, cümleler ve paragraflar kodlama için belirlenerek işaretlenmiştir. Birbirine benzeyen veriler, belirli kodlar ve temalar çerçevesinde bir araya getirilmiş ve anlaşılır bir şekilde düzenlenmiştir. Bu işlem araştırmacı ve başka bir alan uzmanı tarafından ayrı olarak yapılmıştır. Daha sonra yapılan kodlamalar bir araya gelerek karşılaştırılmıştır. Güvenirlik için Güvenirlik= Görüş Birliği/Görüş Birliği+Görüş AyrılığıX100 formülü uygulanmıştır (Miles ve Huberman, 1994). Farklı düşünülen kodlamalarda uzlaşılarak güvenirlik \%100 hesaplanmıştır. Elde edilen kodlar, temaları oluşturmada kullanılmıştır. Bulgular tema başlıklarında betimsel bir anlatım ile sunulmuş, görüşü sayıları frekans olarak verilmiş ve yarı-yapılandırılmış görüşmelerden doğrudan alıntılar yapılarak yorumlanmıştır. Görüşmelerde bir kişi tarafından birden fazla görüş ifade edildiğinden, görüş sayıları toplamı görüşme yapılan kişi sayısından fazla olmuştur.

\section{Bulgular}

Organ bağışı konusunda 7. sınıf öğrencilerinin ve velilerinin görüşlerini ortaya koymayı amaçlayan bu araştırmada, elde edilen bulgular araştırmanın amaçları doğrultusunda farklı başlıklar altında sunulmuştur. Öğrencilerin ve velilerinin görüşleri, frekans sayıları ve doğrudan alıntılar ile birlikte verilmiştir.

\section{Sınıf Öğrencileri ve Velilerinin Organ Bağıșı ve Önemine İlişkin Görüşleri}

Öğrencilerin organ bağışı konusundaki görüşleri; "hayat kurtarır ( $f$ 9), yardımlaşma ve paylaşma duygularını güçlendirir ( $f$ 6), hasta insanlara umut olur ( 2 2), insanların mutlu olmasını ( $f 2)$ ve sevinmesini sağlar (f 1)" biçimindedir. Organ bağışı konusunda öğrencilerin velilerinin görüşleri ise; "insanlara yeni bir hayat verir ( $f$ 4), Organ bağ ļsılnda bulunulmalıdır ( $f$ 4), hayat kurtarır $(f$ 2), yardımlaşma sağlar (f 1 )" biçiminde sıralanabilir.

Öğrenciler çoğunlukla organ bağışını hayat kurtarma olarak görmekte, yardımlaşma ve paylaşma duygularını güçlendirdiğini düşünmektedirler. Bu konuda bir öğrenci görüşünü şöyle ifade etmiştir: "İnsanın, başka insanın hayatını kurtararak yardım etmesi geliyor aklıma mesela. Insanlar kendi organlarını feda edip başkalarının hayatını kurtarıyor". 
Organ bağışının insanlara yeni bir hayat sunduğunu bir veli şöyle dile getirmiştir: "Çok güzel şeyler düşünüyorum, insana yeniden hayat verdiğini. Yani boşu boşuna topră̆ın altına gireceğine organlarımızın faydalı bir insanlara yararlı olması gerektiğini düşünüyorum”.

Öğrenciler organ bağışını; "hayat kurtardı ̆̆g için (f 8), insanlara yeni bir hayat sunduğu için (f 3), ihtiyacı olanlara yardım edilebildiği için (f 2) ve yaşam sevinci oluşturduğu için (f 1)" aileler

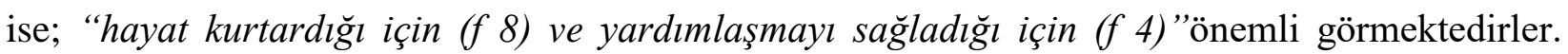
Hem öğrenciler hem de velileri organ bağışını hayat kurtardığı ve yardımlaşma duygularını güçlendirdiği için önemli görmektedirler.

Organ bağışının önemi konusunda bir öğrenci “... Önemli olduğunu düşünüyorum. Çünkü hayatı zindan olmuş bir kişinin hayatını düzeltmek için örneğin sürekli bir tane makinaya bağlı böbreksiz yaşamaktansa, birine böbreğini verip onun hayatını kurtarabiliriz” demiştir. Bu konuda bir veli ise görüşlerini “...organ bağışı bekleyen pek çok insan var, kimi karaciğer, kimi böbrek. Haberlerde duyuyoruz. Bu insanlar için organ bulunması çok önemli, ancak organ nakli hayatlarını kurtarıyor..."sözleri ile ifade etmiştir. Bulgular, organ bağışı konusunun önemsendiğini, öğrenciler ve velilerinin bu konuda olumlu görüşlere sahip olduklarını göstermektedir.

\section{Sınıf Öğrencileri ve Velilerinin Organ Bağışı Konusundaki Bilgileri ve Bilgi Kaynakları}

7. sınıf öğrencileri ve velilerine organ bağışı konusunda neler bildikleri ve bunları hangi kaynaklardan öğrendikleri sorulmuştur. Öğrencilerin organ bağışı konusundaki bilgileri; “organ bağışı için 18 yaşından büyük olmak gerekir (f 7), böbrek bağışlanabilir (f 7), doku uyuşmazlı̆̆l oluşabilir (f 4), beyin bağışlanamaz (f 3), tüm organlar bağışlanamaz (f 2), hem yaşayan hem de ölen kişilerden organ alınabilir ( $f$ 2)" biçiminde sıralanabilir. Öğrenciler aynı zamanda şunları bildiklerini ifade etmişlerdir: "bağışlanan organların sağlıklı olması gerekir $(f 2)$, üç yılda bir organ bă̆ışı yapılabilir (f 2), yüz nakli yapılabilir (f 2), kalp (f 2), karaciğer (f 1), el, kol, deri parçaları ( $f$ 1) ve bazı iç organlar bağışlanabilir (f 1)." “Akciğer bă̆ışlanamaz (f 1), göz yaşarken bağışlanamayan tek organdır $(f 1)$, kan gurubu uyuşmazlı̆̆ı olabilir ( $f$ 1), organ reddi olabilir ( $f$ l)”. "Sadece hasta ya da yaşamının sonuna yaklaşmış kişilerden organ nakli yapılabilir (f 1), bağışlanacak organların testlerden geçmesi gerekir (f 1), organlar, organ bağışı 
onay kâğıld ile băğışlanabilir ( $f 1)$, hastanelerde her zaman yeterli organ bulunmaktadır ( 1$)$, organ bağışı için insanlar sıra beklemek zorunda kalabilir $(f 1)$ ”.

Öğrencilerin organ bağı̧̧ı konusundaki bilgileri çeşitlilik göstermektedir. Öğrencilerin çoğu organ bağışı için 18 yaşından büyük olmak gerektiğini ve böbreğin bağışlanabildiğini bilmektedirler. Bu konuda öğrenciler "18 yaşından büyük olmamamı lazım ve ona göre dokuların uyuşması lazım", "Böbrek falan bağışlanıyor ama beyin olmuyor diye biliyorum" demişlerdir. Ancak "Sadece hasta ya da yaşamının sonuna yaklaşmış kişilerden organ nakli yapılabilir" ve "hastanelerde her zaman yeterli organ bulunmaktadır" görüşlerinde olduğu gibi öğrencilerin kimi bilgilerinin eksik ya da yanlış olduğu görülmektedir.

$\mathrm{Bu}$ öğrencilerin velilerinin organ bağışı konusunda bilgileri ise şöyle sıralanabilir: "Yeterli bilgim yok (f6), doku ve organ bağış belgesi diye bir belge var ( $f 2)$, ölen insanlardan organ alınabilir ( $f$

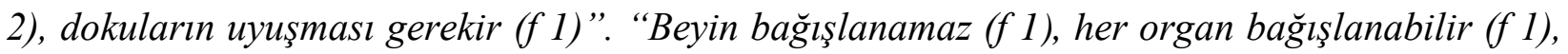
her organ bağışı için beyin ölümü aranmaz $(f 1)$, yaşı çok geçkin insanlardan organ alınmaz ( $f$ 1)”. Organ bağışı konusunda yeterli bilgisinin olmadığını bir veli şu sözlerle açıklamıştır: "Organ bağış̧ıly ilgili daha çok basindan ve işte gazeteden yeterli bilgiyi edinmeye çalışlyoruz ama tabi bazı yanlış aktarılan bilgiler var veya bizlerin tereddüt yaşadığı ya düşüncelerimiz var organ bağışıly ilgili tam yeterince aydınlanmış değiliz bu konu hakkında”.

Bulgular öğrencilerin velilerinin pek çoğunun organ bă̆ışına ilişkin yeterli bilgilerinin olmadığını göstermektedir. "Ölü insanlardan organ alınabiliyor", "her organ bağıışlanabilir" görüşlerinde olduğu gibi kimi aileler de bu konuda eksik ve yanlış bilgilere sahiptirler. Ayrıca bulgular öğrencilerin ailelerine göre organ bağışı konusunda daha fazla bilgiye sahip olduğunu göstermektedir.

Öğrencilerin organ bağışı konusundaki bilgi kaynakları; "televizyon (haberler/kamu spotu/reklam) $(f 7)$, internet $(f 6)$, dersler $(f 5)$, kitap/dergi ( $f 3)$, organ bağış yapan akrabalar ve çevredeki kişiler $(f 1)$, aile $(f 1)$, proje ödevleri $(f 1)$, performans ödevleri $(f 1)$ " biçiminde sıralanabilir. Bilgi kaynağının dersler olduğunu söyleyen öğrenciler bunları; "Sosyal Bilgiler dersi (f 5), Fen Bilgisi dersi ( $f$ 3), Türkçe dersi ( $f$ 1), Hayat Bilgisi dersi ( $f$ 1)" olarak açıklamışlardır. Öğrenciler organ bağışı konusunda farklı kaynaklardan bilgi edinmişlerdir. Organ bağışı konusundaki bilgilerini daha çok televizyondan ve internetten öğrendikleri 
görülmektedir. Görüşme yapılan öğrencilerin ancak yarısı organ bağışını derslerden öğrendiğini ifade etmiştir. Sadece birer öğrenci ise bu konuyu ailesinden ya da ödevler yoluyla öğrendiğini söylemiştir.

$\mathrm{Bu}$ öğrencilerin velilerinin organ bağışı konusundaki bilgi kaynakları ise şöyle sıralanabilir: "televizyon ( $f 6)$, çevredeki kişiler larkadaşlar (f 3), gazete/dergi (f 3), internet ( $f 2)$, seminer ( $f$ 2), hastanelerdeki broşürler (f 1) çocuğumun ödevi ( $f$ 1)”. Aileler bu görüşlerini "Bazen televizyonda organ bağışı konusunda haberler çıkıyor, mesela Akdeniz Üniversitesinde bir hoca var yüz naklinde çok iyi. Haberlerden yüz naklinin Türkiye'de yeni yapılabildiğini ögrenmiş̧tik...", “çocuğun ödevine yardım ederken ögrenmişstim” sözleri ile ifade etmişlerdir.

Bulgular hem öğrencilerin hem de velilerinin organ bağışı konusundaki bilgilerini genelde televizyondan öğrendiklerini göstermektedir. Bu da kitle iletişim araçlarından televizyonun öğrenciler ve aileleri üzerindeki etkilerini göstermesi bakımından oldukça önemlidir. Bunun yanı sıra ailelerine göre öğrenciler üzerinde internetin de etkisi büyüktür.

\section{Sınıf Öğrenci Velilerinin Türkiye'de Organ Bağışıının Durumuna İlişkin Görüşleri}

Araştırmada öğrencilerin velilerine Türkiye'de organ bağışının durumuna ilişkin görüşleri sorulmuştur. Bu konuda kendisiyle görüşülen velilerin tümü "Türkiye'de yeterince organ bağışı yapılmıyor" demişlerdir. Bunun nedenini ise "insanlar organ bağışı konusunda yeterince bilgili değiller (f 5), insanlar dini inançlarından dolayı organ bă̆gşsında bulunmuyorlar (f 3), kültürel yapımız organ bağışıını engelliyor ( $f 2)$ " açıklamalarında bulunmuşlardır.

Veliler bu görüşlerini “...Yok yok yapılmıyor. Binlerce hasta var, gazetelerde okuyoruz, haberlerde dinliyoruz, organ bekleyen binlerce hasta var...”, “...Yani Avrupa'ya göre Türkiye'de bu konu hakkında biraz daha bilinçlenmemiz gerektiğini düşünüyorum...”, “...yok yapılmıyor, maalesef bu konuda çok geriyiz... Ee bence şey dini açıdan olabilir, kültür açısından olabilir, insanlar vermek istiyorlar ama şeyden dolayı eee inançlarından dolayı organ bağışında bulunmuyor olabilir. Yani büyük bir ihtimalle de öyle zaten... Hani versek ne olur, vermesek ne olur. İşte ee caiz midir değil midir falan hani ..." sözleri ile açıklamışlardır. 
Bulgular 7. sınıf öğrenci velilerinin Türkiye'de organ bağışının durumuna ilişkin bilgilerinin sınırlı olduğunu, Türkiye'de dini inançlar ve kültürel yapının organ bağışında bulunmayı engellediğini düşündüklerini göstermektedir.

\section{Sınıf Öğrenci Velilerinin Organ Bağışında Bulunma İstekleri ve Merak Ettikleri Konular}

Araştırmada öğrenci velilerine organ bağışında bulunmak isteyip istemedikleri sorulmuştur. Velilerin bu konuya ilişkin görüşleri şöyledir: “Bu konuyu hiç düşünmedim (f 5), Organ bağışında bulunmayı düşünürüm ( $f$ 3), organlarımı bağışladım ( $f$ l), organ bağışında bulunmayı düşünürüm ama tereddütlerim var (f 1)". Organ bağışında bulunmak istediğini bir veli şu sözlerle ifade etmiştir: “...organ bă̆ışııda bulunmak istiyorum ama bunun için neler yapmam gerektiğini tam net bir şekilde ben de bilmiyorum”. Bir başka veli ise organ bağışında bulunmak isteyip istemediğini hiç düşünmediğini "Hiç düşünmedim. Aslında düşünülmesi gereken bir konu ama ya insan başına gelmeyince bilmiyor bu konuları, yani yakınımızın başına gelse o zaman düşünebilirsin. Insan kendi başına gelmeyince düşünemiyor” sözleri ile açıklamıştır. Bir veli de organlarını bağışladığını şu sözlerle ifade etmiştir: “...biz uzun yıllar organ bağışı bekledik. Kardeşim karaciğerinden rahatsızdı. Onu kaybetmemiz bütün aileyi yıktı... Organlarımı bağışladım”.

Bulgular organ bağışında bulunma konusunda istekli olduğunu belirten veli sayısının \%50'nin altında olduğunu, çoğunluğun bu konuyu ya hiç düşünmediğini ya da bazı tereddütlerinin olduğunu göstermektedir. Bir velinin organlarını bağışladığını belirtmesi araştırmanın dikkat çekici bulgularından birini oluşturmaktadır. Görüşmelerden elde edilen bulgulara dayalı olarak organ bağışı konusunda yaşantıları olan insanların konuya bakış açılarının farklılaştığını ve daha duyarlı olduklarını söylemek mümkündür.

Araştırmada, velilere organ bağışı konusunda merak ettiği konular olup olmadığı ve neleri merak ettikleri sorulmuştur. Velilerin organ bağışı konusunda merak ettikleri farklılaşmaktadır. Bunlar: "Organ bağışı nasıl yapılır? (f 4), hangi organlar bağışlanabilir (f 3), organ bağışı yapmak dini açıdan uygun mudur? (f 2), organ bă̆ışı öldükten sonra mı yoksa ölmeden önce mi yapılmaktadır? (f 1), hangi durumlarda hasta insanlardan organ bă̆ışı yapılmaktadır? (f 1), organ bağışında bulunmak için neler yapılması gerekir? (f 1)” . Bu görüşlerini veliler şu sözlerle açıklamışlardır: “...Nasıl organ bă̆ışı yapılır? Nelerde yapılabilir? Mesela yani hasta olandan 
ne durumdayken organ bağışı yapılabilir...”, “...Ya işin bu ben buna iki boyutlu bakarım yani bir bilim yönünden, bunun hani hangilerinin nakil olup olamayacă̆l yani her organ nakil oluyor mu? Bir de açıkçası dini boyutunda yani dinen bunun şeyi uygun mu? Nakli uygun mudur? Evet, birini yaşatacă̆ız ama yaşatırken de hani bir taşı yerine koyarken de uygun bir harçla koymak önemli...”, “...yani hakikaten ölmeden mi alınıyor yoksa gerçekten ölüm olduktan sonra mı alınıyor merak ediyorum. Çünkü normalde düşünüyorum benim kalbim çalışmadan alınsa başkasının işine yaramayacă̆ını düşünüyorum ... ",

Bulgular, organ bağışı ile ilgili "nasıl yapıldığı, hangi organların bağışlanabildiği, dini açıdan uygun olup olmadığı” gibi konuların en çok merak edilen konular olduğunu göstermektedir. "organ bă̆ışında nasıl bulunulabileceğ i”" konusunu merak ettiğini ise sadece bir veli dile getirmiştir. Bulgulara bakarak velilerin organ bağışı konusunda çok meraklı olmadıklarını, özellikle nasıl organ bağışında bulunulacağını merak etmediklerini söylemek mümkündür.

\section{Velilerin Çocuklarının Organ Bağışı Konusundaki Bilgilerine ve Bu Konudaki Ortak Paylaşımlarına İlişkin Görüşleri}

Velilere çocuklarının organ bağışı konusundaki bilgileri sorulduğunda "yeterli bilgisi yok (f 7), derslerde ögreniyorlar ( $f$ 2), fikrim yok $(f 1)$ ” demişlerdir. Bunun üzerine ailelere çocukları ile organ bağışı konusunu konuşup konuşmadıkları ve bu konuda birlikte herhangi bir paylaşımlarının olup olmadığı sorulduğunda ise şu yanıtlar verilmiştir: "Hiç konuşmadık (f 5 ), bazen konuşuruz (f 2), Fen Bilgisi ödevini yaparken konuştuk (f 1)”. "İşin içinde olduğumuz için hep konuşuyoruz (f 1)”, Sosyal Bilgiler ödevini yaparken konuştuk (f 1), televizyonda haberlerde bu konu çıkınca konuşuruz (f 1)”.

Veliler bu görüşlerini; “bu konuda yeterli bilgisi olduğunu zannetmiyorum”, “...derslerde bu konuyu işliyorlar. Sosyal Bilgiler ya da Fen dersinde böyle bir konuda öğretmen ödev vermiş. Hangi organımız bağışlanamaz falan diye bir soru sorulmuş, o soru üzerinde bayağı durmuştuk. Öğretmenlerimizle falan da iletişime geçmiştik, o zaman konuştuk” sözleriyle açıklamışlardır.

Ailelere çocuklarının organ bağışı konusunda bilgi sahibi olmaları konusunda ne düşündükleri sorulduğunda; "bilgi sahibi olmalılar ( $f$ 8), 13-14 yaşından sonra bilgilendirilmeliler (f 4), ileri yaşlarda öğrenmeleri daha iyi olur (f 2), " demişlerdir. Çocukları ile organ bağışı konusundaki paylaşımlarının neler olması gerektiği sorulduğunda ise şu yanıtlar alınmıştır: “...derinlemesine 
girilmeden konunun önemi anlatılmalı ( 6 6), ders kitaplarından öğrenilenler yeterli olacaktır ( $f$ 2), televizyon programlarında yer alırsa çocuklar bu yolla öğrenebilir (f 2), küçük örneklerle hikayeleştirilerek anlatılabilir ( $f 1)$ ”.

Bulgular ailelerin çocuklarının organ bağışı ile ilgili ne bildiklerinden yeterince haberdar olmadıklarını, çoğunlukla çocukları ile bu konuda herhangi bir paylaşımlarının olmadığını göstermektedir. Çocuklarının bilgi sahibi olmaları gerektiğini düşündükleri halde ne zaman bilgilenmeleri gerektiği konusunda farklı görüşlere sahip oldukları ve çocuklarına konunun öneminin ayrıntılara girilmeden genel olarak anlatılması gerektiğini düşündükleri görülmektedir. Bulgulardan, ailelerin organ bağışı konusu ve bu konuda çocukları ile birlikte yapabilecekleri etkinlikler hakkında bilgilendirilmeye ihtiyaçlarının olduğunu söylemek mümkündür.

\section{Sınıf Öğrencilerinin Sosyal Bilgiler Dersinde Organ Bağış̧ı Konusunun İşlenişine İlişsin Önerileri}

7. Sınıf öğrencilerine Sosyal Bilgiler dersinde organ bağışı konusunun işlenişine ilişkin önerileri sorulduğunda "İnternetten videolar izlettirilmeli $(f 5)$, derste konu ayrintıll işlenmeli ve bol örnek verilmeli $(f 4)$, slaytlar ve görsellerle sunum yapılmalı $(f 4)$ " biçimindedir. Öğrenciler "hastanelere geziler düzenlenmeli $(f 2)$, organ bekleyen ya da organ bağışında bulunmak isteyen kişiler derse getirilmeli $(f 2)$, kitapta daha fazla bilgi olmalı $(f 2)$, derse konuyla ilgili uzman kişiler davet edilmeli ( 2 )" gibi farklı öneriler de getirmişlerdir. Bu konularda, öğrenciler görüşlerini "derste internetten videolar izleyebiliriz. Çeşitli videolar... Organ bağışı bekleyenlerin hayatları ile ilgili olabilir. Bunu izlersek daha iyi anlayabiliriz organ bağışını...", "mesela hastanede organ bağışı bekleyenleri görmeye gidebiliriz...", "hastaneye gezi düzenlenebilir, kоnи ile ilgili bilgilendirmeyi doktor ve hemşireler orada yapabilir" sözleri ile açıklamışlardır.

Bulgulardan, öğrencilerin Sosyal Bilgiler dersinde organ bağı̧̧ı konusunun; bilgisayar ve internet kullanılarak, video, slayt ve çeşitli görsellerden yararlanılarak, konu ile ilgili kişiler derse davet edilerek işlenmesini istedikleri görülmektedir. Ayrıca, hastanelere geziler düzenlenmesini, kitap ve kaynaklarda daha fazla bilgiye yer verilmesini istedikleri anlaşılmaktadır. Öğrencilerin Sosyal Bilgiler dersinde organ bağışının işlenişine ilişkin önerileri oldukça yerinde bulunmuştur. Şüphesiz konu ile ilgili bilgisayar ve internetin kullanılması, çeşitli görsellerden yararlanılması, 
ders kitabı ve kaynak kitaplarda konu ile ilgili daha fazla bilgiye ulaşılması, ilgili kişilerin derse davet edilmesi ya da hastane ziyareti öğrencilerin organ bağışı konusunda bilgi, tutum ve değerlerinin gelişmesi için oldukça önemlidir.

\section{Tartışma ve Sonuç}

$\mathrm{Bu}$ araştırmanın sonunda temelde; 7. sınıf öğrencilerinin ve ailelerinin organ bağışı konusundaki görüşleri belirlenmiştir. Araştırmanın amaçları doğrultusunda beş farklı temada çeşitli sonuçlara ulaşılmıştır. Bu temalardan elde edilen sonuçlar, aşağıda açıklanmış ve tartışılmıştır.

Araştırmanın sonuçlarına göre; öğrenciler ve aileleri, organ bağışını; çoğunlukla hayat kurtarma olarak görmekte, hayat kurtardığı, yardımlaşmayı sağladığı ve yaşama sevinci oluşturduğu için de önemli bulmaktadırlar. Çok sayıda araştırmada, lise ve üniversite öğrencilerinin ya da toplumun farklı kesimlerinin organ bağışı konusundaki görüşleri, bilgileri, tutumları ya da davranışları ortaya konmaya çalışılmaktadır. Araştırmalar çoğunlukla bireylerin organ bağışı konusunu önemli gördüklerini (Bölükbaş Eyüpoğlu ve Kurt, 2004) ve bu konuda olumlu tutum sergilediklerini göstermektedir (Feeley ve Servoss, 2005; Özer ve diğerleri, 2008; Perenc, 2012; Zhang ve diğerleri, 2006). Ancak bireylerin konuya ilişkin bilgilerinin ya da davranışlarının, düşünce ve tutumlarına paralel artmadığı görülmektedir. Organ bağışının, önemli olduğunun düşünülmesine ve olumlu tutum gösterilmesine karşın, insanların bu konudaki bilgileri çoğunlukla yetersizdir (Bölükbaş, Eyüpoğlu ve Kurt, 2004; Chen, 2006; Güngörmüş ve Dayapoğlu, 2014; Kavurmacı, Karabulut ve Koç, 2014). Ayrıca organ bağışından uzak durmaktadırlar (Naçar ve diğerleri, 2001; Kavurmacı, Karabulut ve Koç, 2014; Özkan ve Yılmaz, 2009; Zhang ve diğerleri, 2006).

Araştırmada, öğrenciler ve ailelerinin organ bağışı konusunda neler bildikleri ve bilgi kaynaklarının neler olduğu da tespit edilmiştir. Buna göre öğrenciler, organ bağışı konusunda ailelerinden daha fazla bilgiye sahip olmasına karşın, hem öğrencilerin hem de ailelerinin organ bağışı konusundaki bilgilerinin bir kısmı, eksik ya da yanlıştır. Örneğin öğrencilerin çoğu, organ bağışı için 18 yaşından büyük olmak gerektiğini doğru bilmesine karşın, "hastanelerde her zaman yeterli organ bulunduğu, akciğerin bağışlanamaz olduğu” gibi yanlış bilgilere de sahiptirler. Çalışmanın sonunda, öğrenciler ve ailelerinin organ bağışı konusunda bilgilerinin yetersiz olduğunu söylemek mümkündür. Bu bulguyu destekler biçimde pek çok araştırma, öğrencilerin ya da toplumun organ bağışı konusunda yeterli bilgiye sahip olmadıklarını ortaya 
koymaktadır. Bölükbaş Eyüpoğlu ve Kurt (2004), öğrencilerin ancak \%59,5'inin organ bağışı konusunda bilgilerinin olduğunu, \%69,1'inin ise organ bağışı için ne yapmaları gerektiğini bilmediklerini; Güngörmüş ve Dayapoğlu (2014) da bireylerin ancak \%41,3'ünün organ bağış1 hakkında bazı bilgilere sahip olduklarını ortaya koymuşlardır. Chen ve diğerleri (2006), yaptıkları araştırmada öğrencilerin kan bağışına ilişkin bilgilerinin daha iyi olduğunu; ancak akciğer, deri, kalp ve diğer organların bağışı ve nakline ilişkin farkındalıklarının eksik olduğunu saptamıştır.

Organ bağışı konusunda toplumda bilgi eksikliğini göstermesi bakımından, Savaşer ve diğerleri (2012) tarafindan yapılan çalışma da oldukça dikkat çekicidir. Araştırmada, hemşirelik okuyan öğrencilerin organ bağışı konusundaki bilgilerinin yetersiz olduğu ve bu nedenle eğitim süreci içinde organ bağışı konusunda kapsamlı bilgi verilmesi gerektiği sonucuna ulaşılmıştır. Sağlıkla ilgili bir bölümde okuyan öğrencilerin bile organ bağışı konusunda yeterli bilgiye sahip olmamalarının, toplumda bu konudaki bilgi eksikliğimizi göstermesi bakımından oldukça önemli olduğu düşünülmektedir.

Araştırmada organ bağışı konusunda öğrenciler ve ailelerinin bilgi kaynakları belirlenmiş ve en çok televizyondan öğrendikleri tespit edilmiştir. Bunun yanı sıra, organ bağışı hakkında öğrencilerin, ailelerine göre internetten daha fazla bilgi edindikleri bulunmuştur. Öğrencilerin bilgi kaynakları içinde dersler, kitap ve dergiler, akrabalar, aileler, proje ve performans ödevleri yer alırken; ailelerinin bilgi kaynaklarını; çevrelerindeki kişiler ve arkadaşları, gazete ve dergiler, internet, seminer, hastane broşürleri ve çocuklarının ödevleri oluşturmaktadır. D'alessandro, Peltier ve Dahl (2012) tarafından yapılan çalışmada da organ nakli ve bağışı konusunda öğretmenler tarafından sağlanan bilginin, öğrencilerin bu konuya yönelik tutumunu önemli ölçüde etkileyebildiği, bununla birlikte, aile, medya araçları, sosyal ağların şuan ki gençler için en büyük bilgi kaynakları olduğu tespit edilmiştir. Yapılan farklı araştırmalarda da bu araştırmada olduğu gibi organ bağışı konusundaki bilgilerin, çoğunlukla medyadan öğrenildiği konusunda benzer sonuçlar görülmektedir. Vicdan, Peker ve Üçer (2011), yaptıkları araştırmanın sonunda, öğrencilerin organ bağışı konusundaki bilgi kaynaklarının daha çok radyo ve televizyon olduğu sonucuna ulaşmışlardır. Akgün, Tokalak ve Erdal (2002), üniversite öğrencilerinin \%55,9'unun organ bağışı ve nakli ile ilgili bilgilerini medya aracıllğı ile öğrendiklerini; Güngörmüş ve Dayapoğlu (2014) da bireylerin organ bağışı konusundaki bilgilerinin \%56,7'sini medya aracıllı̆ı ile öğrendiklerini bulmuşlardır. Zhang ve diğerleri (2006) ise bu çalışmanın aksine öğrencilerin 
organ bağışı konusundaki bilgilerinde toplumsal eğitim ve reklamların çok az etkili olduğunu ya da hiç etkisinin olmadığını tespit etmişlerdir.

Medyanın insanlar üzerindeki etkisi bilinmektedir. Bu araştırmada da öğrenciler ve ailelerinin organ bağışı konusundaki bilgilerini genelde bu yolla öğrenmiş oldukları görülmektedir. $\mathrm{Bu}$ nedenle medyanın bu konudaki sorumluluğu yadsınamaz. Öğrenciler ve ailelerinin organ bağışı konusundaki bilgi ve tutumlarını geliştirecek programlara başta televizyon olmak üzere çeşitli medya unsurlarında yer verilmesinin önemli olduğu düşünülmektedir.

Araştırmada, Türkiye'de organ bağışının durumuna ilişkin ailelerin görüşleri de belirlenmiş ve bu konudaki bilgilerinin sınırlı olduğu bulunmuştur. Ailelerin Türkiye'de dini inançlar ve kültürel yapının organ bağışında bulunmayı engellediğini düşündükleri tespit edilmiştir. Kavurmacı, Karabulut ve Koç (2014) da sosyal, fen ve sağlık bilimleri gibi farklı bölümlerde okuyan üniversite öğrencilerinin organ bağışı konusundaki bilgi ve görüşlerini belirledikleri araştırmalarında, öğrencileri \%47,4'ünün vücut bütünlüğü bozulduğu ve \%2,5'inin dini inançlarına ters düştüğü için organ bağışında bulunmayı düşünmediklerini tespit etmişlerdir. Oysa Diyanet İşleri Başkanlığı Din İşleri Yüksek Kurulu tarafından 06.03.1980 tarih ve 396/13 sayılı kararı ile "organ naklinin caiz olduğu” açıklanarak organ bağışının dini açıdan sakıncalı olmadığı belirtilmiştir (TRT Türk Haber Akış1, 2016). Güngörmüş ve Dayapoğlu (2014) da yaptıkları çalışmanın sonunda din adamlarının organ bağışı hakkında bilgi vermeleri ve bu konuda toplumu cesaretlendirmeleri gerektiğini açıklamışlardır.

Araştırmanın sonunda ulaşılan bir diğer sonuç ise ailelerin organ bağışı konusuna çok fazla ilgi duymadıkları ve merak etmedikleridir. Araştırmada, organ bağışında bulunma konusunda istekli olduğunu belirten veli sayısı oldukça düşüktür. Aileler en çok "organ bağışıııın nasıl yapıldığını, hangi organların bağışlanabileceğini, organ bağışıııın dini açıdan uygun olup olmadığını, organ bağışında bulunmak için neler yapılması gerektiğini" merak etmektedirler. Perenc ve diğerleri (2012) de Polonyalı üniversite öğrencilerinin organ bağışı konusunda pozitif niyetlerinin olmadığını açıklayarak, organ bağışı konusunda istekli olmadıklarını ve bu konuda eğitim programlarının geliştirilmesi gerektiğini ortaya koymuşlardır. Fakat yapılan bu araştırmanın aksine Bölükbaş Eyüpoğlu ve Kurt (2004) yaptıkları araştırmanın sonunda, üniversite öğrencilerinin \%59,6'sınınn organ bağışında bulunmak istediğini ancak \%69,1'inin ise organ bağı̧ı1 için ne yapmaları gerektiğini bilmediğini, Zhang ve diğerleri (2006) ise çok sayıda 
üniversite öğrencisinin hayattayken organ bağışında bulunmaya istekli olduklarını tespit etmişlerdir.

Araştırmalarda, öğrencilerin organ bağışında bulunmaya istekli oldukları ortaya konmasına karşın, bunun davranışa dönüştürülüp dönüştürülmediğine ilişkin herhangi bir bilgi bulunmamaktadır. Oysa bu konuda bireylerin istekli olup olmadığının asıl göstergesi; 18 yaşından büyük olan ve organ bağışında bulunan kişilerin sayısı olabilir. Bununla birlikte, çeşitli araştırmalarda katılımcıların organ bağışında bulunmak için ne yapmaları gerektiğini bilmedikleri sonucuna ulaşılması, bu kişilerin organ bağışında da bulunmadıkları biçiminde yorumlanabilir. Farklı araştırmalarda, Bölükbaş, Eyüpoğlu ve Kurt (2004) öğrencilerin \%69,1'nin; Özmen ve diğerleri (2008) katılımcıların \%57'sinin; Özkan ve Yılmaz (2009) da katılımcıların \%92'sinin, organ bağışında bulunmak için ne yapmaları gerektiğini bilmedikleri sonuçlarına ulaşmışlardır. Benzer biçimde Naçar, ve diğerleri (2001) de tıp fakültesi son sınıf öğrencileriyle yaptıkları çalışmada öğrencilerin organ bağışında bulunmak için hangi kuruma başvuracaklarını bilmediklerini saptamışlardır. Araştırmada ulaşılan başka bir sonuç da yakın çevresinde organ bağışı bekleyen ailelerde, organ bağışına bakış açılarının farklılaştığının ve kendi yaşantılarından dolayı bu konuya daha duyarlı olduklarının ortaya çıkarılmasıdır.

Ailelerin organ bağışı konusunda istekli ve olumlu tutuma sahip olmalarının sağlanmasında, sadece Sosyal Bilgiler öğretmenlerinin değil, okul yönetimlerinin ve okuldaki diğer öğretmenlerin de sağlı çalışanları ile birlikte yapacağı eğitim çalışmalarının önemli olduğu düşünülmektedir. Koçak ve diğerleri (2010) araştırmalarının sonunda, bireylerin okulda organ bağışı konusunda eğitilmesi, organ bağışı kampanyalarının organize edilmesi, medya desteğinin sağlanması ve organ bağışında bulunanlara (donörlere) devlet tarafindan finansal destek sağlanması gerektiğine yönelik öneriler getirmişlerdir. Bununla birlikte Sosyal Bilgiler öğretmenleri kendi dersleri kapsamında organ bağışı konusunda aile katılımını sağlayan etkinlikler düzenleyebilirler, aileler ve çocuklarının daha fazla paylaşımda bulunmalarını sağlayabilirler. Annadurai, Mani ve Ramasamy (2012) da öğrencilerinin bilgi ve tutumlarını geliştirmek için öğretmenlerin konuyla ilgili etkinlikler yapmaları gerektiğini vurgulayarak bunu desteklemektedir. Nitekim bu araştırmada bazı öğrenciler, organ bağışı konusundaki bilgi kaynakları içinde dersler ve ödevleri sayarak, ders kapsamında yapılacak etkinlik ve çalışmaların öğrenciler için önemini ortaya koymuşlardır. Diğer taraftan araştırmalarda organ bağışı 
konusunda yapılacak eğitim için en uygun yaşın 10-11 yaş civarında olduğunun vurgulanması (Siebelink, Roodbol, Albers ve Van de Wiel, 2014b), bu yaş grubunda Sosyal Bilgiler dersi kapsamında yapılacak çalışmaların önemini ortaya koyması bakımından önemlidir.

Dünyada organ bağışı konusunda geliştirilen çeşitli öğretim programları, öğrencilerin bilgi ve tutumlarının olumlu yönde değişmesinde etkili olmuştur. Örneğin Shu ve diğerleri (2011) geliştirdikleri "The One Life... Many Gifts” adlı öğretim programının, Vinokur ve diğerleri (2006) de uyguladıkları internet tabanlı öğretimin öğrencilerin organ ve doku bağışına ilişkin tutumları üzerindeki olumlu etkisini göstermişlerdir. Dolayısıyla organ bağışı konusunda öğrencilerin ve ailelerinin birlikte paylaşımlarını artıracak, bilgi ve tutumlarını olumlu yönde etkileyecek öğretim programlarının geliştirilmesi gerektiği düşünülmektedir.

Ailelerin, çocuklarının organ bağışı ile ilgili ne bildiklerinden yeterince haberdar olmadıkları, ama çocuklarının bu konuda bilgi sahibi olmaları gerektiğini düşündükleri sonucuna ulaşılmıştır. Bununla birlikte çoğunlukla çocukları ile bu konuda herhangi bir paylaşımlarının olmadığı tespit edilmiştir. Yine bu araştırmada öğrencilerden sadece birinin, ailesini bilgi kaynağı olarak göstermesi, öğrencilerin aileleri ile bu konuda paylaşımlarının yetersiz olduğunu desteklemektedir.

Son olarak 7. Sınıf öğrencilerinin Sosyal Bilgiler dersinde organ bağışı konusunun işlenişine ilişkin önerileri belirlenmiştir. Öğrencilerin önerileri; Sosyal Bilgiler dersinde organ bağışı konusunun; bilgisayar ve internet kullanılarak, video, slayt ve çeşitli görsellerden yararlanılarak, konu ile ilgili kişiler derse davet edilerek işlenmesi, hastanelere geziler düzenlenmesi, ayrıca kitap ve kaynaklarda daha fazla bilgiye yer verilmesi biçiminde olmuştur. Öğrencilerin önerilerinin Sosyal Bilgiler dersinde organ bağışı konusunun işlenişinde etkililiği artıracağı, öğrencilerin konu ile ilgili bilgi, tutum ve değerlerinin gelişmesi için önemli olduğu düşünülmektedir.

Araştırmanın sonuçları doğrultusunda, öğrenciler ve ailelerinde, organ bağışı konusundaki farkındalığı ve ilgiyi arttırmak amacıyla çeşitli öneriler getirilebilir:

- Organ bağışı konusunda, 6. sınıf Sosyal Bilgiler dersi öğretim programını destekleyen ve aile katılımını sağlayan çeşitli etkinlik örnekleri ve materyaller hazırlanabilir. Bunlar, 
öğretmenleri desteklemek ve işlerini kolaylaştırmak için cd, kitap vb. araçlar ile onların kullanımına sunulabilir.

- Yurt dışında olduğu gibi ilköğretim düzeyinde, organ bağışı konusunda hem öğrencilerin hem de ailelerinin birlikte yüz yüze ya da internet üzerinden katılabileceği çeşitli eğitim programları düzenlenebilir. Bunların etkililiğini ortaya koyan çeşitli araştırmalar yapilabilir.

- Sosyal Bilgiler dersi kapsamında konu ile ilgili kişiler derse davet edilebilir, hastane ya da konuyla ilgili merkez/birimlere ziyaretlerde bulunulabilir.

- Organ bağışı konusunda öğrencilerin aileleri ile paylaşımlarını arttırmaya yönelik, birlikte hazırlayabilecekleri proje ve ödevler verilebilir. Bu çalışmaların öğrenciler ve ailelerinin bilgi, tutum ve görüşlerine etkileri araştırılabilir.

- Organ bağışın konusunda ortaokul öğrencilerinin farklı sınıf düzeylerinde bilgi, tutum ve görüşlerini belirlemeye yönelik araştırmalar yapılabilir.

\section{Kaynakça}

Akgün, S., Tokalak, I., Erdal, R. (2002). Attitudes and behavior related to organ donation and transplantation: a survey of university students. Transplant Proc. 34(6), 2009-11.

Akış, M., Katırc1, E., Uludağ, H. Y., Küçükkılıç, B., Gürbüz, T., Türker, Y., Kayacan...Gül, H. (2008). Süleyman Demirel üniversitesi personelinin organ-doku bağış1 ve nakli hakkında bilgi ve tutumları, Süleyman Demirel Üniversitesi Tip Fakültesi Dergisi. 15(4): 28-33.

Annadurai, K., Mani, K. ve Ramasamy, J. (2012). a study on knowledge, attitude and practices about organ donation among college students in chennai, tamil nadu. Prog Health Sci, $3(2), 59-65$.

Balcı, E. ve Şahingöz, M. (2014). Hemşirelerin organ bağışına bakışları, Cumhuriyet Medical Journal, 36(4), 503-511.

Bogdan, R. C. and Biklen, S. K. (2007). Qualitative research for education: An introduction theories and methods (5th ed.). Boston, MA: Pearson Education.

Bölükbaş, N., Eyüpoğlu, A. ve Kurt, P. (2004). University students' thoughts about organ donation, Journal of Experimental and Clinical Medicine, 21(2), 73-77. 
Burra, P., De Bona, M., Canova, D., D'Aloiso, M. C., Germani, G., Rumiati, R., Ermani, M., Ancona, E. (2005). Changing attitude to organ donation and transplantation in university students during the years of medical school in Italy. In Transplantation Proceedings. 37 (2), 547-550.

Çelebi, F., Balık, A. A., Yılmaz, İ. ve Polat, K. Y. (2002). Doğu Anadolu bölgesi insanı organ bağışına nasıl bakıyor?. Türkiye Klinikleri Journal Of Medical Ethics-Law And History, 10(1), 34-38.

Cheng, B., Ho, C. P., Ho, S. ve Wong, A. (2005). An overview on attitudes towards organ donation in Hong Kong, Hong Kong Journal of Nephrology, 7(2), 77-81.

Chen, J. X., Zhang, T. M., Lim, F. L., Wu, H. C., Lei, T. F., Yeong, P. K. ve Xia, S. J. (2006). Current knowledge and attitudes about organ donation and transplantation among chinese university students. In Transplantation Proceedings. 38(9), 2761-2765.

Creswell, J. W. (2007). Qualitative inquiry \& research design choosing among five approaches (2nd ed.). London, UK: Sage.

D’Alessandro, A. M., Peltier, J. W., A. J. Dahl (2012). The impact of social, cognitive and attitudinal dimensions on college students' support for organ donation. American Journal of Transplantation, 12, 152-161.

Demir, T. (2008). Organ nakli ve diyaliz ünitesinde çalışan sağlık profesyonellerinin organ/doku bağışı ve nakline yönelik yaklaşımlarının değerlendirilmesi. Yayınlanmamış Yüksek Lisans Tezi, Marmara Üniversitesi Sağlık Bilimleri Enstitüsü, İstanbul.

Doğan, P., Toprak, D., Sunal, N. ve Doğan, İ. (2012). Türkiye'de üniversite öğrencilerinin organ nakli konusundaki bilgi, tutum ve davranışları, Smyrna Tıp Dergisi, 1, 16-25.

Doğanay, A. (2005). Öğretimde kavram ve genellemelerin geliştirilmesi, C. Öztürk ve D. Dilek (Ed), Hayat Bilgisi ve Sosyal Bilgiler Öğretimi içinde (s. 265- 296). Ankara: Pegem Akademi.

Febrero, B., Ríos, A., López-Navas, A., Martínez-Alarcón, L., Almela, J., Sánchez, Á., Sanchez, S., Pairrilla, J. J., Ramirez, P. ve Parrilla, P. (2014). A multicenter study of the attitude of 
secondary school teachers toward solid organ donation and transplantation in the southeast of spain. Clinical Transplantation, 28(2): 259-266.

Feeley, T. H., Servoss, T. J. (2005). Examining College Students' İntentions To Become Organ Donors, Journal of Health Communication, 10(3), 237-249.

Güngörmüş, Z. ve Dayapoğlu, N. (2014). The knowledge, attitude and behaviour of individuals regarding organ donations, TAF Preventive Medicine Bulletin, 13(2): 133-140.

Kavurmac1, M., Karabulut N. ve Koç, A. (2014). Üniversite öğrencilerinin organ bağış1 hakkındaki bilgi ve görüşleri, Hemşirelikte Eğitim ve Araştırma Dergisi, 11(2), 15-21.

Kılıç, S., Koçak N., Türker, T., Gürpınar, H. ve Gülerik, D. (2010). Kız üniversite öğrencilerinin organ bağışı konusundaki tutumları ve bu tutumlarına etki eden faktörler. Gülhane Tip Dergisi,52 (1), 36-40.

Koçak, A., Aktaş, E. Ö., Şenol, E., Kaya, A., Bilgin. (2010). U E. Ege University Faculty of Medicine undergraduates' knowledge level regarding organ donation and transplantation. Ege Med , 49 (3), 153-160.

Milli Eğitim Bakanlığı (2005). Illköğretim sosyal bilgiler ögretim programı, Talim Terbiye $\begin{array}{lllll}\text { Kurulu } & \text { Başkanlığı, } & \text { Ankara. } & \text { Erişim } & \text { Tarihi: }\end{array}$ http://ttkb.meb.gov.tr/program2.aspx

Milli Eğitim Bakanlığı (2013). İlköğretim Kurumları (İlkokullar ve Ortaokullar) Fen Bilimleri Dersi (3, 4, 5, 6, 7 ve 8. Sınıflar) Öğretim Programı, Talim Terbiye Kurulu Başkanlığg, Ankara. Erişim Tarihi: 15.01.2016 http://ttkb.meb.gov.tr/www/guncellenen-ogretimprogramlari/icerik/151

Miles, M. B. and Huberman, M. A. (1994). An expanded sourcebook qualitative data analysis. London, UK: Sage.

Naçar, M., Çetinkaya, F., Kanyılmaz, D., Tokgöz, B. ve Ulaş, C. (2001) . Hekim Adaylarının Organ Nakline Bakış Açıları. Türk Nefroloji Diyaliz ve Transplantasyon Dergisi. 10, 123 128.

Özdağ, N. (2004). Halkın organ bağışı ve nakline bakış1. Nefroloji Hemşireliği Dergisi, 1(1), 4650 . 
Özdağ, N. (2001). Organ nakli ve bağışına toplumun bakışı. Cumhuriyet Üniversitesi Hemşirelik Yüksekokulu Dergisi, 5(2), 46-55.

Özer, F. G., Karamanoğlu, A. Y., Beydağ, K. D., Fidancığlu, H., Akıncı, E., Şanlı, İ., ... Urak, S. (2008). Sağlik Yüksekokulunda Öğrenim Gören Bir Grup Öğrencinin Organ Nakli/Bağışına Yönelik Görüşleri ve Bilgi Düzeylerine Eğitimin Etkisi, Türk Silahları Kuvvetleri Koruyucu Hekimlik Bülteni, 7(1), 39-46.

Özkan, S. ve Yılmaz, E. (2009). Hasta yakınlarının organ bağışı ile ilgili bilgi ve tutumları. Aile ve Toplum Eğitim, Kültür ve Araştırma Dergisi, 5(17), 18-29.

Özmen, D., Çetinkaya, A. Ç., Sarızeybek, B. ve Zeybek, A. (2008). Celal bayar üniversitesi Manisa sağlık yüksekokulu öğrencilerinin organ bağışına ilişkin bilgi ve görüşleri. Turkiye Klinikleri Journal of Medical Sciences, 28(3), 311-318.

Perenc, L., Radochonski, M.ve Radochonski, A. (2012). Knowledge and attitudes of polish university students toward organ donation and transplantation, Psychology, Health \& Medicine, 17(6), 667-673.

Savaşer, S., Mutlu, B., Çağlar, S., Doğan, Z. ve Canbulut, N. (2012). Hemşirelik Son Sınıf Öğrencilerinin Organ Bağışına Bakışları. Florence Nightingale Hemşirelik Dergisi, 20(1), 1-9.

Siebelink, M. J., Albers, M. J. I. J., Roodbol, P. F, and Van de Wiel H. (2014a). An online explorative study towards parents' opinions about organ donation: from individual decisions to family discussions. Archivos Argentinos de Pediatria, 112(3), 224-230.

Siebelink, M., Roodbol, P., Albers, M. and Van de Wiel H. (2014b). A lesson about organ donation in primary school: support for its development and its effects, American Journal of Transplantation, 14, 822 .

Shu, J., ve diğerleri (2011). Impact of the educational resource one life... many gifts on attitudes of secondary school students towards organ and tissue donation and transplantation, Transplantation Proceedings. 43(5), 1418-20. Erişim Tarihi: 10.07.2015 http://www.ncbi.nlm.nih.gov/pubmed/21693209

Sönmez, V. (1997). Sosyal bilgiler öğretimi, Ankara: Anı Yayıncılık. 
TRT Türk Haber Akışı, (2016). Organ nakli nedir? Organ bağışı neden önemlidir? Erişim

Tarihi:4 Ocak 2016

http://www.trtmemleketimfm.com/?r=site/haber\&kaynak=trt_turk\&haber_id=haber/organ -nakli-nedir-organ-bagisi-neden-onemlidir-160393.html

Vicdan, A. K., Peker, S. ve Üçer, B. (2011). Akşehir sağlık yüksekokulu öğrencilerinin organ bağışı ile ilgili tutumlarının belirlenmesi, TAF Preventive Medicine Bulletin, 10(2), 175 180.

Vinokur, A. D., Merion, R. M., Couper, M. P., Jones, E. G. ve Dong, Y. (2006). Educational web-based intervention for high school students to increase knowledge and promote positive attitudes toward organ donation. Health Education \& Behavior, 33(6), 773-786.

Yaşar, M., Oğur, R., Uçar, M., Göçgeldi, E., Yaren, H., Tekbaş, Ö. F. ve Korkmaz, A. (2008). Bir sağlık meslek yüksekokulu son sınıf öğrencilerinin organ bağışı konusundaki tutumları ve tutumlarına etki eden faktörler, Genel Tip Dergisi, 18(1), 33-37.

Yeter, E. ve Demirtaş, S. (2015). Organ nakilleri ve organ bağışının önemi, Erişim Tarihi: 10.08.2015https://www.google.com.tr/url?sa=t\&rct=j\&q=\&esrc=s\&source=web\&cd=1\& $\mathrm{cad}=\mathrm{rja} \&$ uact=8\&ved=0ahUKEwie67SLpJfKAhXFuBQKHQTZAJIQFggaMAA\&url=htt p\%3A\%2F\%2Fkisi.deu.edu.tr\%2Fbulent.cavas\%2Fders\%2Fbok3.doc\&usg=AFQjCNEm 001IKS8dmnK4Q2ouQSyJmK81VA\&bvm=bv.110151844,d.d24

Yıldırım, A. and Şimşek, H. (2013). Sosyal bilimlerde nitel araştırma yöntemleri (9th ed.). Ankara: Seçkin Yayıncılık.

Yücetin, L., Keçecioğlu, N., Ersoy, F. F. (2003). Türkiye’de organ bağış1 ve nakline bir bakış. Dialysis, Transplantation and Burns 14(2), 115-118.

Zhang, L., Li, Y., Zhou, J., Miao, X., Wang, G., Li, D., Nielson, K., Long, Y. ve Li, J. (2007). Knowledge and willingness toward living organ donation: a survey of three universities in changsha, hunan province, china, Transplantation Proceedings, 39(5), 1303-1309. 


\section{EXTENDED ABSTRACT}

In recent years, organ donation has been covered in different curricula at schools. Organ donation is important for social studies course because of its societal, biological, religious and judicial reasons. "Tissue and Organ Donation" topic is covered in the curriculum of social studies course taught at the sixth grade in the "Electronics Century" Unit in the "Science, Technology and Society" learning domain. The curriculum has an outcome "expresses the relation between breakthroughs and developments in medicine and human life and solidarity" concerning the topic. The recommended activity to attain this outcome is "Saving a Life (Studying organ transplantation and stories of people transforming some peoples' lives by donating organs.)"

To what extent the mentioned outcome and activity influences students' views about organ donation is deemed to be worth studying. Research concerning the importance of organ donation in education has mainly conducted on university students. In this study, the views, knowledge, and attitudes of university students towards organ donation and the factors affecting students' attitudes were examined. Apart from these studies, there is some research aiming to determine the knowledge, attitude, behaviour and views of society, patient relatives and healthcare professionals about organ donation. Studies conducted abroad with different age groups stand out among others. These studies examine the implementations and programs developed about organ donation and the knowledge, attitudes and behaviours of students, parents and teachers regarding organ donation are determined. In Turkey, there is not a study carried out on organ donation at the sixth grade social studies course taught at primary school level. Therefore, this study aimed to obtain the views of students who studied the topic of organ donation in the sixth grade social studies course at primary school level. However, since the views and attitudes of students and their parents about this topic were also thought as significant, the purpose of the study was to determine the views of seventh grade students and their parents about organ donation. The research questions posed for this study are as follows: What are the views of students and their parents about organ donation and its significance? What is the knowledge and source of knowledge of students and their parents about organ donation? How much do the parents know about the situation of organ donation in Turkey? What are the attitudes of parents towards organ donation? What are the views of parents regarding their children's knowledge about organ donation and their mutual interaction on this issue? 
The phenomenological research design which is a kind qualitative research method was employed in the study. There were two requirements in selecting the participants. For students it was studying the organ donation subject; for parents, it was becoming the parents of those students who were interviewed. The data were obtained through semi-structured interviews conducted in the spring term of 2014-2015 academic year. In order to get in-depth information from the participants, several interviews were carried out, which is aligned to the research design. The data collected were examined via content analysis. The findings were descriptively presented under different themes. The views were presented as frequencies and interpreted by direct quotations.

The findings were analysed under five different themes according to the purpose and questions of the research. The results revealed that the students and their families regard organ donation significant as it saves life, contributes to helping each other and creates joy of life. It was found that the students know more about organ donation in comparison to their families. However, both the students and their families have either wrong or imperfect knowledge about organ donation and their knowledge about organ donation is limited to television.

It was found that the parents' knowledge about organ donation is limited. They believe that the religious and cultural structure hinder people from organ donation and the views of people who have experience with organ donation may change and they become more sensitive to the issue; however; they are not so interested in organ donation. The study also found that parents are not necessarily aware of what their students know about organ donation and they do not interact with their children about this subject. In light of the study, some recommendations can be presented in order to raise awareness in students and their families about organ donation: Some sample activities and materials about organ donation supporting the curriculum of the sixth grade social studies course and encouraging family participation can be prepared and they can be submitted to teachers. As it is abroad, some educational programs on organ donation which will enable both students and their families to attend either face-to-face or online can be designed for the primary school level. 